Article

\title{
Circular Economy: Questions for Responsible Minerals, Additive Manufacturing and Recycling of Metals
}

\author{
Damien Giurco $^{1, *}$, Anna Littleboy ${ }^{2}$, Thomas Boyle ${ }^{1}$, Julian Fyfe ${ }^{1}$ and Stuart White ${ }^{1}$ \\ 1 Institute for Sustainable Futures, University of Technology, Sydney (UTS), \\ P.O. Box 123, Broadway, NSW 2007, Australia; E-Mails: thomas.boyle@isf.uts.edu.au (T.B.); \\ julian.fyfe@uts.edu.au (J.F.); stuart.white@uts.edu.au (S.W.) \\ 2 Commonwealth Scientific and Industrial Research Organisation (CSIRO), Queensland Centre \\ for Advanced Technologies, P.O. Box 887, Kenmore, QLD 4069, Australia; \\ E-Mail: anna.littleboy@csiro.au \\ * Author to whom correspondence should be addressed; E-Mail: damien.giurco@uts.edu.au; \\ Tel.: +61-2-9514-4978; Fax: +61-2-9514-4941.
}

Received: 10 December 2013; in revised form: 4 March 2014 / Accepted: 21 March 2014 / Published:6 May 2014

\begin{abstract}
The concept of the circular economy proposes new patterns of production, consumption and use, based on circular flows of resources. Under a scenario where there is a global shift towards the circular economy, this paper discusses the advent of two parallel and yet-to-be-connected trends for Australia, namely: (i) responsible minerals supply chains and (ii) additive manufacturing, also known as 3D production systems. Acknowledging the current context for waste management, the paper explores future interlinked questions which arise in the circular economy for responsible supply chains, additive manufacturing, and metals recycling. For example, where do mined and recycled resources fit in responsible supply chains as inputs to responsible production? What is required to ensure 3D production systems are resource efficient? How could more distributed models of production, enabled by additive manufacturing, change the geographical scale at which it is economic or desirable to close the loop? Examples are given to highlight the need for an integrated research agenda to address these questions and to foster Australian opportunities in the circular economy.
\end{abstract}

Keywords: additive manufacturing; megatrends; industrial ecology; circular economy; stewardship; recycling 


\section{Introduction}

The dynamics of global resource availability and modes of production and consumption are changing in radical ways. Throughout much of the 20th century, the real prices of most metals were in gradual decline, however in the 21 st century real prices have risen, due to strong demand from rapidly industrializing countries like China, as well as supply side factors including deteriorating resource quality and capacity constraints from under-investment $[1,2]$.

In an analysis of future global trends, affecting not only production and consumption, the Commonwealth Scientific and Industrial Research Organisation (CSIRO) Megatrends report [3] identifies six megatrends which are expected to play out in coming decades. Megatrends are defined as interlinked significant shifts in social, environmental and economic conditions, namely:

(1) More from less: companies, governments and communities will discover new ways of ensuring quality of life for current and future generations within the natural world's limited resources;

(2) Going, going, ... gone? Many of the world's natural habitats, plant species and animal species are in decline or at risk of extinction. This megatrend also captures the issue of climate change;

(3) The silk highway: The powerhouses of the new world economy are China and India and, to a lesser extent, South America and Africa; billions transition from poverty to the middle classes;

(4) Forever young: Overall the ageing population is an asset in skills, knowledge, wisdom - whilst rising healthcare costs and limited retirement savings are a challenge;

(5) Virtually here: We are increasingly moving online to connect, to deliver and access services, to obtain information and to perform transactions such as shopping and working;

(6) Great expectations: This is a consumer, societal, demographic and cultural megatrend noting the rising demand for experiences over products and the rising importance of social relationships.

These trends have implications for resource use and in particular metals, which is the focus of this paper. The result of Trend (1) may be a greater focus on urban mines and scrap as stocks of the future and the development of the circular economy, given resource constraints on primary production (economic, social and environmental). Additionally, there is the potential for efficiency improvements in the preparation of ores during mining and the reprocessing of mining waste (for example iron from "red mud" waste from alumina refining). A further trend is in rising consumer demand for socially and environmentally responsible products that has occurred at the same time as an increasing focus on responsible mineral production [4].

Recent studies have shown that potential mineral scarcity is as significant as the much discussed issue of energy scarcity [5-7]. These findings point firmly in the direction of recycling, as limited resources can be used preferentially to recycle materials in order to extract much needed minerals, including critical minerals needed for future energy infrastructure Indeed, this mineral scarcity has the potential to make recycling a necessity, rather than a choice. Recycling changes not only the scale and location of production, but also value centers in the production consumption chain. In parallel, new forms of manufacturing such as additive manufacturing are opening up potential for distributed and customized rather than mass production and it is unclear whether this will help or aggravate efforts to close the loop. 
This paper asks: how will a move towards the circular economy and the evolution of future manufacturing trends affect responsible supply chains and the potential for increased recycling, based on an overview of the current state of waste recycling in Australia? Following an overview of the circular economy (Section 2), the importance of responsible supply chains to the circular economy-from both primary and secondary production is discussed (Section 3). Section 4 explores the disruptive technology of additive manufacturing which has the potential to radically alter geographies of production where used, and in turn, the geographical scale at which metal cycling and recycling occurs in the economy. Before discussing the future potential and pitfalls facing the advent of the circular economy in Australia in Section 6, Section 5 provides an overview of the Australian context for mining, manufacturing and waste, namely the starting point for the transition to realizing wealth from waste.

\section{Circular Economy}

The concept of the circular economy is gaining increasing prominence, notably in China [8-11] but also in the UK where the concept was described in 1990 [12]. A recent report by the Ellen Macarthur Foundation [13], Towards the Circular Economy, also connects its development with the fields of regenerative design, industrial ecology, performance economy and cradle to cradle.

\subsection{The Drivers of a Circular Economy}

The concept of a circular economy is gaining momentum due to a combination of factors, all of which result in the extraction of greater utility from available resources:

- Continued and forecast growth in demand for metals, and other materials will be driven, to a large extent, by economic growth in Asia [14];

- However, there is a gradual decline in mineral ore grades [15,16] - the data reveal that for many mineral commodities ore grades are declining as the richer deposits have been increasingly extracted;

- Increased generation of waste material - ten years ago, around 0.68 billion $\mathrm{t}$ of urban municipal solid waste was generated globally each year. Today, this has increased to around 1.3 billion $t$ and by 2025 it is likely to reach 2.2 billion t per year [17];

- Rising costs of waste disposal-globally, solid waste management costs will increase from $\$ 205.4$ billion per year today, to about $\$ 375.5$ billion in 2025 . These cost increases will be most severe in low income countries (more than 5-fold increases) and lower-middle income countries (more than 4-fold increases) [17];

- There has been a significant improvement in the evolution of recycling technology for metals [18] — product complexity has been a significant barrier for recycling due to the effort required to separate materials of interest. Coming decades, however, will see the continued advancement of chemical and physical processes for recycling and computer tools to aid the recycling process. This will make recycling more efficient and less costly;

- Demand for more sustainable mining practices - significant pressure remains to reduce energy consumption in order to reduce operational costs as well as stem greenhouse gas emissions. 
Producing aluminium from recycled sources requires 95\% less energy than producing it from virgin materials [19] and copper reclaimed through recycling also requires $75 \%$ less energy for low quality scrap [20] through to over 90\% less energy than the amount needed to convert copper ores to metal $[21,22]$;

- Consumer demand for responsible products has risen as environmental certification standards have grown and matured, mostly for primary metals, and seeing this also addressed for secondary materials is an important issue [23].

Manufacturing is arguably the cornerstone of the circular economy as the design, composition and assembly of products will, by and large, determine the ease with which materials can be recovered. Innovation in manufacturing - the progression of advanced manufacturing - is set to redefine the global manufacturing landscape in the years ahead with respect to material flows.

Growing global competitiveness will continue to reshape how and where products are made. In parallel shifting externalities of production and consumption will increasingly transcend national economic boundaries to be felt at the global scale, in doing so challenging once accepted practices: the creation and export of hazardous waste increasingly scrutinized [24], the "locking-up" and dispersion of waste resources increasingly interrogated. The value of recovery - the sheer necessity of the circular economy - will become further evident with rising costs of extraction and processing of virgin resources. Innovation in manufacturing will thus be driven by global competitiveness and resource efficiency. In parallel with developments in responsible supply chains, some firms have begun to experiment with design for disassembly in a bid to improve competitiveness or in response to government moves to introduce extended producer responsibility policy (as exemplified by the Japanese experience [25]).

\subsection{The Concept of a Circular Economy}

The Circular Economy concept aims for circular flows of resources in the economy (as opposed to the currently dominant linear flows from extraction through use to landfill disposal. It is framed as an economic imperative more than an environmental imperative and has been described at three spatial levels: [9]

(i) The individual firm level using cleaner production;

(ii) Eco-industrial park level with clustered or chained industries/responsible supply chain;

(iii) Between production and consumption systems in regions, between industries and urban environment in an "eco-region" or municipality.

As such, the circular economy distinguishes itself from industrial ecology through a stronger "economy" focus. Yet, it does not have the same established intellectual tradition of debate regarding the concept, as has occurred with industrial ecology over the last twenty years. More work is needed to connect the concept with, for example, the ecological economics literature and describe appropriate indicators of the circular economy at the three scales identified above. This is begun usefully by [26] for China yet they note: (i) a lack of social indicators for the circular economy; (ii) a lack of indicators on urban/industrial symbiosis; (iii) a lack of indicators for business; (iv) a lack of absolute (rather than relative) indicators for material/energy reduction; and (v) a lack of cleaner production/prevention 
option indicators (for example, limiting inputs of toxics to a process may be better than achieving a high recycling rate for the toxic material). Consequently, these are important areas of further research.

A generalized illustration of the concept of the circular economy is given in Figure 1. The focus in this paper is on metals (which fits into the blue half of the diagram).

Figure 1. Circular economy for renewable and non-renewable resources. (Reproduced with permission from [13]. Copyright 2013 Ellen Macarthur Foundation).

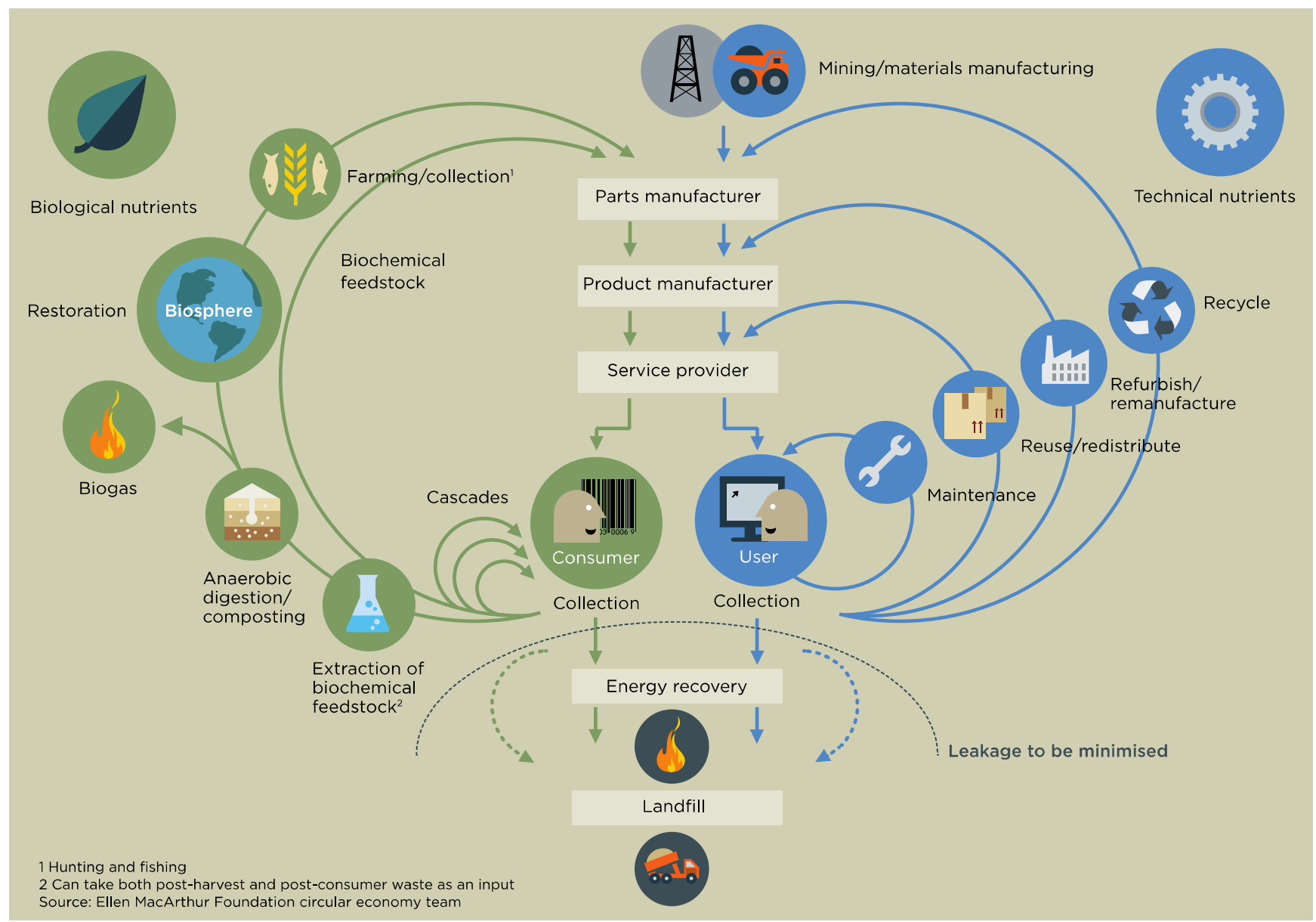

The usefulness of the cascaded representation in Figure 1 is to illustrate that smaller loops (closer to the user) are generally lower impact - for example, the reuse or remanufacture of a mobile telephone compared to the recycling of a mobile phone (or manufacture of a new phone with virgin materials). The Ellen Macarthur Foundation Report [13] further identifies that new business models will be part of the new economic approach and that sources of value creation (whilst being ultimately dependent on geography and the global product within the supply chain) in a circular economy can be identified as:

- Inner circles: offering greater substitution of embedded costs for materials, labor, energy;

- Circling longer: through better design to make products last longer, be repairable;

- Cascaded uses: such as old clothing into fiber for furniture;

- Pure, non-toxic inputs, easy to separate designs: this aims to have purer material streams to improve reuse and recycling potential. 
The last point in particular, represents a point of tension, between designing high performing systems with complex material inputs which are also complex to recycle, versus simpler systems which are simpler to recycle. This needs to be considered carefully at a time when additive manufacturing is disrupting business models of centralized mass production. It is also important to mention that there will always be losses from a recycling system as dictated by the Second Law of Thermodynamics and highlighted by Reuter et al. [18], who note that "Concepts such as "Closing the loop", "Circular Economy" and "Cradle-to-Cradle" represent unattainable ideal conditions, but they bring systemic thinking into material-efficiency discussions, and provide an upper limit to the potential economic benefits". Delivering the circular economy also offers opportunities for new business models (for example leasing, rather than selling).

\subsection{The Global Significance of the Circular Economy}

Demonstrating the significance of the circular economy for the global economy-given China's global importance - is the writing of "Circular economy" into China's Twelfth Five Year Plan (2011-2015). Quoting in full from the English translation [27] of "Chapter 23: Vigorously Develop Circular Economy":

"We will aim to improve the output efficiency of resource utilization, strengthen planning guidance, support fiscal and monetary policies, perfect the laws and regulations, implement extended producer responsibility and propel all links between production, circulation and consumption. We will speed up the development of the resource recycling industry, comprehensively utilize mineral resources, encourage the recycling of industrial waste, upgrade recycling systems and waste separation and recovery of renewable resources, and advance the industrialization of renewable resource recycling. We will encourage low carbon consumption models and lifestyles among the people and government. Our development model should adopt resource reduction, recycling, remanufacturing, zero emissions and industry links and popularize the classical recycling economic model."

Given China's significance as both supplier and consumer of commodities on the global stage (and is role as Australia's most significant two-way trade partner [28], this commitment is highly significant and will play out through the following supply/demand trends.

At the point where the demand for certain minerals exceeds production levels, recycling (where possible) will be required to fill the supply-demand gap. Looking at copper as an example, predictions see copper reserves meeting global demand until around 2040 [29]. After this point, there will either need to be a reduction in the amount of copper consumed, or a significant increase in the supply of copper coming from secondary resources, providing a strong economic incentive for recovery.

A second trend is the rise of substitute materials. Nickel pig iron was developed in China as a cheaper alternative to pure nickel for use in the production of stainless steel. Nickel pig iron usage accounted for $25 \%$ of Chinese stainless steelmaking raw materials in 2011, up from $16 \%$ in 2008 . Graphene (a single-atom thick sheet of hexagonally-arranged carbon atoms) is being touted as having the potential to act as a substitute for silicon, steel and even copper due to its strength and thermal 
conductivity ( $\mathrm{F} \& \mathrm{~S}$ and Flores). And with a density similar to that of gold, tungsten is being used as a substitute for gold in jewelry. If the demand for minerals and metals continues to outpace production, these substitutes may rise in popularity. While there is no doubt that the expected future mineral supply deficit will create a need for alternatives to mined ore, it is unclear how much of this deficit will be filled by substitutes versus secondary materials.

For Australia - both in terms of being a supplier into China's circular economy and the development of circular economy within Australia-considering how responsible mineral supply chains will evolve in perception, practice and partitioning between primary and secondary supply is important.

\section{Responsible Supply Chains: Contributions from Primary and Secondary Resources}

Responsible supply chains are considered a mechanism for supporting the effective operation of a circular economy. Despite the "economic" framing of the circular economy literature, seeking environmental and social benefits remain parallel objectives. Business is already engaging in the development of responsible supply chain and stewardship initiatives across a range of commodities - from palm oil [30], forestry [31] and gold [32] to jewelry [33] and steel [34]. Their aim is to improve social and environmental impacts along the supply chain to give the consumer confidence that the product has been sourced responsibly. The origins of different schemes have ranged from avoiding overharvesting for forestry to avoiding conflict minerals and poor environmental performance for gold. Schemes are yet to offer a "carbon neutral" or "biodiversity neutral" level of certification. However, reducing the total level of consumption is not a feature of the schemes, nor is the potential for the rebound effect addressed (see [35] for a description of the rebound effect). Consequently a more comprehensive approach to analyzing cyclical flows of resources would also consider rates of use and dematerialization potential [36].

An additional question arising from the use of responsible supply chain schemes for metals is whether "responsibly sourced" is represented more by:

(i) a mine where the workers are well paid and which utilitises clean energy and processing practices, or;

(ii) whether the metal comes from recycled post-consumer scrap (or even home scrap/recycled production waste).

This is an open question and context dependent, highlighted here to show that it's important to keep the complexity present in the evolving landscape. Any preference for recycled metal also comes with the problem of potentially encouraging shorter product lifetimes or production efficiencies in order to create a larger supply of scrap. It also implies that that recycling practices will be cleaner and more socially responsible. This is not always the case as highlighted by e-waste recycling practices in developing countries [37,38] and also in developed countries like the USA, the last operating secondary copper smelter was closed in 2001 and was under suit for allegedly dumping contaminated water, facing pressure from permitting authorities and uncertain economic viability [39]. The unmet need for certification of responsible supply chains involving secondary resources has been highlighted by Schluep [23]. In the absence of such certification, both "cleaner" and "dirtier" input materials to 
recycling and the recycling processes themselves may remain undistinguished and represents a barrier to the development of the circular economy.

Currently, recycling rates vary by metal from less than $1 \%$ for lithium and rare earths to over $50 \%$ for copper and iron [40]. However, for most metals, increasing overall demand means supply from secondary sources is unlikely to displace primary production (platinum may be an exception due to supply capacity constraints and the influx of available scrap from catalytic converters in diesel cars now entering the scrap market). Resource intensity (kg used per \$GDP) in the Asia-Pacific is also rising, relative to the rest of the world [41].

A key point is that while responsible mineral supply chains have tended to focus on responsible production at the mine, in future, demonstrating responsible production at the recycling facilities will be just as important for reputation as well as certifications. The location at which raw materials (primary or secondary) interface with manufacturing, for example Australian mined commodities into metals and manufacturing in China (or Australia); or, metals from e-waste generated in Australia being recovered and used in manufacturing in Australia (or China), will be influenced by changes to manufacturing technologies. New additive manufacturing technologies in turn influence manufacturing geography which is discussed in the next section.

Finally, considering the future of responsible supply chains in a circular economy, it is necessary to recognize that the purchase of responsible consumer products will be increasingly influenced by the use of social media to share information on responsible products and supply chains [13], with imagery highlighting any untrue claims of environmental or social performance readily able to be posted online and thus increasing scrutiny and accountability.

\section{Future Trends in Additive Manufacturing}

This section outlines trends in future manufacturing, in particular the potential for additive manufacturing and the potential for the consumer as a designer, highlighting synergies and tensions with responsible supply chains in the circular economy.

Additive manufacturing (AM) is of particular interest as it exemplifies the features of advanced manufacturing: customization, automation, increasingly data intensive, and is fast becoming the defining manufacturing technology of the twenty-first century. With greater potential for smaller scale, distributed manufacturing, AM also raises questions about future geographies of manufacturing and the implications for materials reuse and recovery.

\subsection{Overview of Additive Manufacturing}

The growth of AM is set to be a defining element of advanced manufacturing in the twenty-first century. AM actually describes a suite of patented technologies that allows for the production of a growing spectrum of goods from artificial organs [42] to rockets [43] via the layering or "3D printing" of materials [44]. What began in the 1980s with technology development to aid Rapid Prototyping is now increasingly being used for "final" products [45], in particular, for parts production. Between 2012 and 2017, the global AM market is expected to experience an annual growth rate of 13.5\% [46]. $\mathrm{AM}$ is seen as a hallmark of advanced manufacturing owing to its reliance on information technology and its ability to underpin a future of mass customisation and flexible production, and is already the 
source of significant cost savings in some industries owing to the reduced need for tooling and material and energy inputs required for the production of goods relative to conventional subtractive manufacturing processes $[47,48]$. As the technology has matured, so have the range of feedstock materials and end-product applications. Initially limited to plastics, AM is now being used for the production of metal parts (for example, titanium, aluminum, steel, silver) in aerospace, medical, dental and other industries [47]. The growth in metal parts production presents an opportunity for mineral rich countries to leverage AM to create value-adding products. Australia's CSIRO AM Technology Roadmap for example, notes that "with its vast mineral resources, Australia is in a position to produce materials, such as titanium, and use them to create high-value products that are sold domestically and internationally" [48].

Indeed, the scalability and automation of production AM offers has the potential to transform the global manufacturing landscape not only by redefining geographies of production and consumption but also in blurring the lines between producers and consumers [49], such that "almost anyone, located almost anywhere, can now become a manufacturer without a lot of upfront cost, risk or machinery. With CAD software, design creativity, and an Internet connection, one can develop and market a wide range of products from a company or a home" [48]. Our interest lies in what a possible future of distributed localized manufacturing from 3D production systems would mean for the circular economy. Note that a distinction is sometimes drawn between 3D production systems (additive manufacturing) denoting larger scale, higher cost, able to handle multiple materials and 3D printing as smaller scale. This distinction on scale can be useful as some use the terms 3D printing or additive manufacturing loosely as umbrella terms. The extent to which future manufacturing will be distributed-whether the future of $3 \mathrm{D}$ printers will be analogous to the home document printing revolution-remains the subject of some debate. Some commentators argue the majority of consumers will be interested in what is most convenient, and that will involve purchasing AM products through online providers [50,51] for shipping or local pick-up. Others see a greater market for "consumer production". Microsoft for example, having included native support for 3D printing in its latest operating system, sees a future in which 3D printing "will be just as easy and seamless as 2D printing" [52]. Ultimately the future probably lies in both of these scenarios; a mix of localised production and globalised trade, dictated by available energy budgets, feedstock materials, design expertise and complexity of assembly — constraints which are already at play in the global manufacturing landscape, but which will play out in different ways in the years to come (such as carbon pricing, oil prices, etc.). How might this AM future play out within a circular economy? The following scenarios are considered.

\subsubsection{Extension of Product-Use Lifetimes}

Much has been said about the potential of AM to extend product lifetimes by improving the affordability of manufacturing replacement parts. To fulfil this vision, products will need to be designed for maintenance, repair and overhaul (MRO), meaning ease of assembly/disassembly, as the extent to which products will be repaired by consumers will ultimately be driven by cost and convenience (time and skill) factors. 


\subsubsection{Mass Customization, Targeted Production}

The ability of AM to offer mass customization could spell an end to the generation of superfluous stock, with less of a one size fits all approach typical of today's manufacturing. However, this scenario is only foreseeable in the event of two concurrent trends: a greater appreciation of and general up-skilling in design across the population, and the simplification of computer-aided design software accessible to the everyday consumer. Indeed, we are already beginning to see these trends unfold with the establishment of business such as Shapeways Inc., which allows people to make, sell and buy 3D printed objects online [53]. Pre-designed product templates will also bridge the gap between original product design and the desire for unique products.

\subsubsection{Consumer Assembly, Design for Disassembly}

A highly localized geography of AM may drive the design of products to be more readily assembled by consumers themselves if cost and convenience factors permit. This scenario would also depend on the ability of AM machines to manufacture and assemble mechanically complex, working products - the difference between assembling the parts of a 3D printed clock versus 3D printing a the assembled clock itself, for example. The obvious opportunity to be had here lies in the ease of disassembly which in turn aids materials recovery.

\subsubsection{Induced Production}

In the event AM becomes ubiquitous and very cheap, a scenario of induced production may arise (countering any reductions described in Section 4.1.1). That is, AM could lead to the manufacture of high volumes of bespoke products. The question is to what extent this quantity of goods would surpass the production of superfluous goods today. Impacts of material use and disposal would need to be carefully examined and would necessitate greater focus on designing such products from the outset for reuse and recovery, thereby increasing their value as waste resources to be used as feedstock for the manufacture of new goods.

\subsubsection{Enabler of Local Recycling}

The technology could allow greater on-shoring of high quality manufacturing in Australia and foster the recovery of metals locally as it provides a local manufacturing base to feed with recovered metals and couple with new business models such as "leasing" of responsibly sourced (and recovered) metals.

\subsubsection{Materials Complexity}

AM technology is at a critical stage in development where designers and manufacturers are experimenting with new composite materials (including biomaterials). Whilst this experimentation will no doubt continue into the future, the need for political and research agendas around developing and identifying materials that can be efficiently recovered and reused is needed now [54].

All of the above scenarios speak to the implications of material flows in a future of distributed, localised manufacturing realised by ubiquitous AM. Ultimately, they illustrate the potential for AM to 
either aggravate or help address issues of resource dispersion. Crucially, whilst AM represents a fundamental change in the manufacturing process, it will still require a concerted collective effort to ensure designing for disassembly and recovery does not rest solely on the market's response to the demand for consumer product assembly, for this alone will not guarantee circular production.

\subsection{Design}

The role of design is not explored in detail in this paper, however, it must be acknowledged as a key factor which will determine the role which additive manufacturing plays in the circular economy. Design pertains not only to products and whether they are easy to disassemble, but also to the challenge of identifying new business models for a circular economy.

The next section reviews the Australian context for trends in disposal, collection and recycling to provide a basis for evaluating the challenges and opportunities of a circular economy.

\section{Australian Context for Trends in Mining, Manufacturing, Disposal, Collection and Recycling Including Metals}

Whilst the main focus in this section is on the context regarding opportunities to generate wealth from waste, a brief overview of the Australian context for mining and manufacturing is given, particularly for the international reader.

\subsection{Context for Mining}

Australia has significant resource deposits - including of coal, iron, gold, copper, nickel, uranium, zinc, alumina - and resource exports were valued at over \$160 billion in 2011-2012, representing more than half of Australia's exports [55]. Recent years have seen an expansion in investment in new projects and this has now peaked and the industry is entering a production phase. Whilst mining accounts for $8 \%$ of GDP [56], weaker commodity prices have also led to some mines closing. Discussion of sustainability considerations (including the role of recycling) are detailed in reports by Giurco et al. [57,58].

\subsection{Context for Manufacturing}

Australia has a broad based manufacturing industry, however its recent competitiveness has been hampered by a high energy costs and a high Australian dollar (hurting exports) driven up by the commodity boom in minerals. This has led to announcements of planned closures of all car manufacturing plants in Australia, as well as selected closures of steel and aluminium factories. Whilst additive manufacturing only represents one part of the future manufacturing landscape, its potential to enable more decentralized modes of production does alter the competitive advantage of countries, including Australia. 


\subsection{Context for Waste Disposal, Collection and Recycling}

Current waste practices, evolving from predominantly linear resource flows, influence future challenges and opportunities. Over the past two decades, Australia has experienced strong economic growth. This growth has been accompanied by growth in waste produced per capita, which rose from $1970 \mathrm{~kg}$ per capita in 2006-2007 to $2140 \mathrm{~kg}$ per capita in 2010-2011 [59,60]. Waste disposed to landfill, however, has stabilised in most states and territories due to improvement in resource recovery rates across most states and territories, with the notable exceptions of Queensland and Western Australia. This highlights that increasing rates of recycling alone is insufficient for progressing to a circular economy and absolute flows must also be considered.

Growth in waste volumes and higher resource recovery targets have helped the recycling industry grow substantially over the past decade. Between 2002-2003 and 2006-2007 revenue from recycled material grew by $8 \%$ [61]. Landfill is the dominant form of disposal as incineration was largely phased out by the 1970s due to public concerns over air pollution, however energy from waste projects are being actively discussed and the state of New South Wales has recently completed consultation on a draft policy for energy from waste.

Industrial ecology is also gradually gaining traction in Australia (currently for example in areas such as Kwinana in Western Australia, and Gladstone in Queensland and for future consideration in the Latrobe Valley in Victoria [62-64]). At this stage in its development, reuse and recycling directly between industries makes only very small contributions to resource recovery that has not generally been included in broad analyses of recycling, hence the contribution to metals recovery by industrial ecology is not covered here. Similarly, reuse of metal-bearing products is not addressed here, is information on this loop is not readily available. A detailed discussion of the development of IE in Australia is presented in an accompanying paper [65].

\subsubsection{Brief history of Metals Recycling}

The recycling industry has historically not had the same level of high tech research and innovation focus as mining and smelting/refining in Australia. Comalco began its aluminium can recycling program around 1971 and Alcoa in 1977, and by the late 1980s both companies were involved in promotional programs and house-to-house collections. Kerbside collection and recycling of steel cans from households was also established by BHP and steel can manufacturers during the 1990s. In addition, scrap merchants have remained active participants in the recycled metals trade for other metals such as copper. E-waste recycling began in the 2000s and is strengthened with the product stewardship legislation targeting televisions and computers (see Section 5.3.2).

Household recycling had shifted from an ad hoc and industry-run activity, mainly for aluminium cans and glass bottles, to an essential service provided by local government and paid for by ratepayers. Avoidance of paying landfill levies that are now in force in most states provides a strong incentive to recycle metals in addition to the reasonable profit margins now accessible in the scrap metal market.

The evolution of the scale of the sector over the last decade is shown in Table 1. 
Table 1. Overview of scrap metal recycling industry in Australia. (Reproduced with permission from [66]. Copyright 2013 IbisWorld Pty Ltd.).

\begin{tabular}{cccccccccc}
\hline Year & $\begin{array}{c}\text { Revenue } \\
\mathbf{( \$ m )}\end{array}$ & $\begin{array}{c}\text { IVA } \\
\mathbf{( \$ m )}\end{array}$ & $\begin{array}{c}\text { Establishments } \\
\text { (Units) }\end{array}$ & $\begin{array}{c}\text { Enterprises } \\
\text { (Units) }\end{array}$ & $\begin{array}{c}\text { Employment } \\
\text { (Units) }\end{array}$ & $\begin{array}{c}\text { Exports } \\
\mathbf{( \$ m )}\end{array}$ & $\begin{array}{c}\text { Imports } \\
\mathbf{( \$ m )}\end{array}$ & $\begin{array}{c}\text { Wages } \\
\text { (\$m) }\end{array}$ & $\begin{array}{c}\text { Domestic } \\
\text { demand (\$m) }\end{array}$ \\
\hline $2003-2004$ & 2301.3 & 369.6 & 175 & 107 & 3625 & 1011.2 & 78.9 & 204.6 & 1369.0 \\
$2004-2005$ & 2496.6 & 386.0 & 180 & 114 & 3720 & 1047.7 & 78.4 & 209.1 & 1527.3 \\
$2005-2006$ & 2908.2 & 381.8 & 181 & 115 & 3739 & 1319.6 & 76.6 & 211.8 & 1665.2 \\
$2006-2007$ & 3233.0 & 379.4 & 201 & 121 & 3759 & 1359.2 & 71.6 & 216.0 & 1945.4 \\
$2007-2008$ & 3487.9 & 429.0 & 205 & 123 & 3995 & 1476.9 & 75.0 & 233.6 & 2086.0 \\
$2008-2009$ & 3574.9 & 334.9 & 196 & 118 & 3974 & 1620.6 & 77.4 & 233.2 & 2031.7 \\
$2009-2010$ & 3073.8 & 326.9 & 195 & 119 & 3855 & 1380.7 & 68.1 & 226.9 & 1761.2 \\
$2010-2011$ & 3182.6 & 332.6 & 193 & 118 & 3766 & 1472.7 & 68.3 & 220.6 & 1778.2 \\
$2011-2012$ & 3110.1 & 252.0 & 190 & 119 & 3625 & 1447.1 & 64.0 & 215.7 & 1727.0 \\
$2012-2013$ & 3064.1 & 293.0 & 188 & 120 & 3592 & 1456.2 & 63.8 & 216.4 & 1671.7 \\
\hline
\end{tabular}

It shows that revenue in the sector has grown whilst the number of enterprises and employees is relatively steady. The influence of new business models linked to the circular economy (e.g., leasing, extended product lifetimes using repair parts from 3D printers) has yet to significantly affect waste flows.

\subsubsection{Current Waste Policy Landscape}

States and territories hold responsibility for waste management and regulation, but management is undertaken by local government in accordance with state/territory regulatory frameworks. Since the 1970s, waste-related legislation and regulation has evolved to embrace the avoidance, minimization and recovery principles of the waste hierarchy. Resource recovery policy measures prevalent in Australia include recycling targets, landfill levies, CDL in South Australia and the Northern Territory, and limited instances of landfill bans (e.g., computers in the Australian Capital Territory (ACT)) [61]. Unlike many economically advanced countries, Australia has only recently begun to introduce product stewardship policy instruments. National product stewardship legislation was enacted by the Federal Government in 2011 (Product Stewardship Act 2011), providing a framework for accreditation of voluntary schemes, and establishment of co-regulated and mandatory schemes. Stemming from this Act are the Product Stewardship (Televisions and Computers) Regulations 2011, which requires large importers and manufacturers of television and computer products to become members of an "approved co-regulatory arrangement" through which targets related to provision of collection services, recycling rates and material recovery must be met. There are also a number of national, industry-led voluntary product stewardship schemes that affect metals recovery in operation, including mobile phones collection and recycling scheme (e.g., Mobile Muster) and the Australian Battery Recycling Initiative.

\subsubsection{Waste Collection and Resource Recovery}

There is a general trend in the industry towards consolidation into large service providers, although there remains a range of business sizes in scrap metal recycling.

Collection and resource recovery of mixed non-hazardous waste is shown in Table 2. 
Table 2. Classification of waste streams, collection and recovery.

\begin{tabular}{|c|c|c|}
\hline Waste Stream & Collection Services & Resource Recovery \\
\hline $\begin{array}{l}\text { Municipal Solid } \\
\text { Waste (MSW) }\end{array}$ & $\begin{array}{l}\text { Kerbside landfill and recyclables collection contracted or } \\
\text { provided by local or state government. }\end{array}$ & $\begin{array}{c}\text { Mixed recyclables to MRF. General waste } \\
\text { may be treated in AWT before } \\
\text { landfill disposal. }\end{array}$ \\
\hline $\begin{array}{l}\text { Commercial \& } \\
\text { Industrial }(\mathrm{C} \& \mathrm{I})\end{array}$ & $\begin{array}{l}\text { Fragmented — individually negotiated by businesses } \\
\text { depending on nature and volume of waste stream. }\end{array}$ & $\begin{array}{l}\text { Mixed recyclables to MRF. Only a } \\
\text { fraction of mixed waste treated by AWTs } \\
\text { due to variability in content and volume. }\end{array}$ \\
\hline $\begin{array}{c}\text { Construction \& } \\
\text { Demolition (C\&D) }\end{array}$ & $\begin{array}{l}\text { Form of service depends on nature and volume of } \\
\text { waste. Small residential jobs typically use skip bins. } \\
\text { Large demolition sites serviced directly by a C\&D } \\
\text { waste processor, or indirectly via a waste collection } \\
\text { services provider. }\end{array}$ & $\begin{array}{l}\text { Source separated may be delivered } \\
\text { directly to re-processing facility. } \\
\text { Otherwise sent to transfer station. }\end{array}$ \\
\hline
\end{tabular}

\subsubsection{Recovery Rates}

Metals are present in all waste streams, municipal, Commercial \& Industrial (C\&I), Construction \& Demolition. Recycling rates for all metals in 2008-2009 were reported to be $89 \%$ as shown in Table 3 [60].

Table 3. Metal waste generated and recovered for each Australian state and territory.

\begin{tabular}{cccc}
\hline Jurisdiction & Generation (kg per capita) & Recovered (kg per capita) & Recovery rate (\%) \\
\hline NSW & 252 & 227 & 90 \\
Victoria & 218 & 202 & 93 \\
Queensland & 179 & 156 & 87 \\
South Australia & 212 & 192 & 90 \\
Western Australia & 214 & 168 & 78 \\
Tasmania & 27 & 2 & 9 \\
Australian Capital Territory & 123 & 107 & 87 \\
Northern Territory & 45 & 4 & 8 \\
\hline National & 212 & 188 & 89
\end{tabular}

A review of waste and recycling in the C\&I sector produced estimates of national recovery rates in 2010-2011 for steel, aluminium and other non-ferrous metals of $83 \%, 81 \%$ and $88 \%$, respectively [67]. These were considered conservative as they were based on materials separated at the source by generators when separation can occur further along the waste chain. Transport, postal and warehousing was found to achieve the highest overall rate of recycling in the sector $(86 \%)$, but produces only $3 \%$ of the sector's waste load. Manufacturing was the largest waste producer at 3.9 million tonnes per year or $32 \%$ of total C\&I waste, but also the second best recycler at $67 \%$ overall recovery and $96 \%$ recovery of waste metals. The sectors achieving low rates of recycling include wholesale trade, retail trade, education and training, although these sectors produce smaller quantities of waste metals.

Surprisingly, recycling of post-consumer steel cans amounts to around $30 \%-32 \%$ of total steel can consumption (2007-2008), but has been rising since 2002 [68,69]. Other figures are higher at 57\%, highlighting variability in reliable data, but as shown in Figure 2 this rate is still low internationally. It also seems low in the context of $93 \%$ of households having access to steel can recycling services. It 
should also be noted that collection and sorting rates are not equivalent to recycling rates. For example in New South Wales steel cans recovered from domestic waste are exported and have not been recycled locally since the production of tinned steel sheeting ceased and with it the capacity to de-tin steel cans. Aluminium can recycling is more effective at $67.4 \%$ in 2010 [69], presumably due to the high value of the material, the presence of container deposit legislation (CDL) and local reprocessing and refining facilities (that are soon to close).

Figure 2. World steel can recycling rates (2007). (Reproduced with permission from [70], original data from [71]. Copyright 2011 Elsevier).

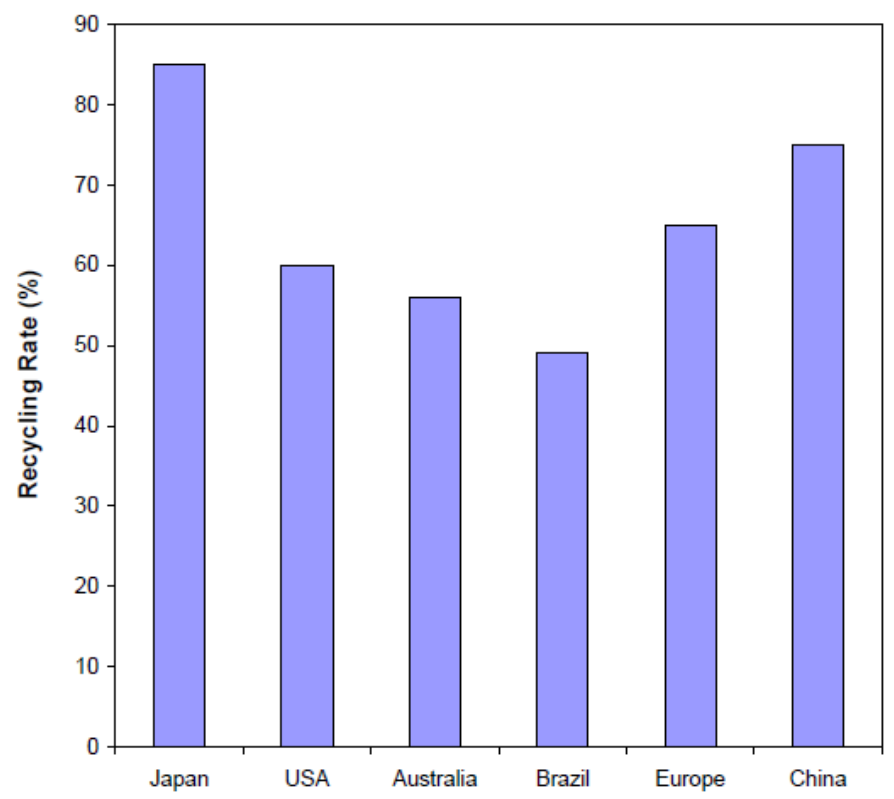

Rates of resource recovery are affected by market demand and commodity prices. Recovery of metals (ferrous and non-ferrous) tends to be relatively stable as there is strong demand, collection and processing costs tend to be low enough to keep prices below virgin material prices, and contamination is relatively low [59]. However, this is not always the case. A drop in scrap prices of $75 \%$ between October 2008 and February 2009, causing Australia's largest scrap recycler to stop buying and withdraw services in regional areas [61]. Recycled metals are also at a competitive disadvantage due to virgin resource extraction and refining activities having economies of scale beyond those currently possible in the collection and reprocessing of recovered materials, and direct and indirect subsidization of mining.

\subsubsection{Reprocessing Infrastructure}

As indicated earlier in the case of steel cans, a significant gap in the materials recovery loop in Australia is the lack of re-manufacturing infrastructure in the recycling industry, which has made it more attractive for companies to export recovered recyclables instead of performing value-adding operations in Australia.

Australia was the world's leading producer of bauxite and alumina in 2011 and the fifth largest aluminium producer. Australia's aluminium industry continues to be a highly integrated sector of mining, refining, smelting and semi-fabrication and is of major economic importance nationally and 
globally. Sims Metal has a dedicated secondary aluminium facility in Melbourne, in addition to Alcoa's secondary aluminium smelter which accepts cans. The announced closure of the Yennora aluminium recycling facility in mid 2014, puts a cloud over the future of aluminum recycling in Australia. City-based recycling operations for other metals may be considered where technology development and value opportunities align.

The question in relation to the circular economy is: where is the greatest opportunity to capture value, either social, economic or even avoided negative environmental value - and then, what connections would be required, for example, between waste infrastructure, additive manufacturing possibilities and responsible mineral supply chains to position Australia for success?

\section{Concluding Discussion}

Recognizing the scale of the shift required and the nature of production, consumption and waste management in Australia, the discussion begins with a powerful conclusion from Preston [72]:

"The circular economy offers a transformational agenda that aims to redesign global production and consumption systems. Many of the ideas are decades old, but a combination of environmental and resource price pressures, technological advancements and changes in consumer demand is finally building momentum. Both the private sector and governments increasingly recognize that future competitiveness will depend on leadership in resource-related innovation."

What are the implications of the circular economy for recycling metals in Australia? Based on the current state of waste management legislation and practice in Australia, significant work will be required to realize circular economy opportunities. For example, container deposit legislation, whilst operating successfully in South Australia and the Northern Territory is still yet to be introduced in Australia's most populous states of New South Wales and Victoria; and even where aluminium cans are collected, they may now be exported instead of recycled locally due to the closure of a secondary aluminium smelter in NSW. However, experience is being gained by industry and government in the operation of the product stewardship legislation nationally for televisions and computers. As this gets reviewed, attention should also turn to implications of the role of "responsible secondary supply chain certification" on future rules. Furthermore, the potentially disruptive influence of additive manufacturing must be considered. As shown in the scenarios described, it has the potential to reduce material throughput and extend product lifetimes, but without ensuring design for disassembly overall results may be mixed. Additional foresight work to understand the ramifications from plausible scenarios, not only for additive manufacturing, but also for the circular economy at different scales is needed to extend the baseline analysis from this paper.

By way of identifying important future directions, Table 4 outlines a spectrum of future research questions structured at different scales which would need to be addressed in a way which recognizes connections and dependencies between scales. Illustrative examples for steel, gold and aluminium are used to show the diversity of issues present. 
Table 4. Connections between future research agendas for the circular economy in Australia.

\begin{tabular}{|c|c|c|c|}
\hline Theme & Australia (at local sites) & Australia (at sector/economy level) & $\begin{array}{l}\text { Implications for Australia as a } \\
\text { supplier to global customers }\end{array}$ \\
\hline $\begin{array}{l}\text { Circular } \\
\text { economy }\end{array}$ & $\begin{array}{l}\text { How can existing examples of established } \\
\text { industrial ecology precincts (e.g., Gladstone, } \\
\text { Kwinana) be used to develop best practices } \\
\text { and global leadership? }\end{array}$ & $\begin{array}{l}\text { What awareness raising is required to adequately address } \\
\text { the future significance of the circular economy (for } \\
\text { example given policy level commitments in China and } \\
\text { Japan)? What indicators are appropriate? }\end{array}$ & $\begin{array}{l}\text { What is Australia's niche in terms } \\
\text { of primary and secondary supplier } \\
\text { and new business models under a } \\
\text { circular economy? }\end{array}$ \\
\hline $\begin{array}{l}\text { Responsible } \\
\text { supply chains }\end{array}$ & $\begin{array}{l}\text { How may local supply chains be affected if } \\
\text { 3D printing enables distributed } \\
\text { manufacturing? }\end{array}$ & $\begin{array}{l}\text { What can be learned from the Steel Stewardship Forum } \\
\text { and the Responsible Jewellery Council for new } \\
\text { geographies of production and consumption from primary } \\
\text { and secondary sources? }\end{array}$ & $\begin{array}{l}\text { Can Australia lead the development } \\
\text { of chain of custody standards into } \\
\text { China whilst promoting Brand } \\
\text { Australia? }\end{array}$ \\
\hline Steel & \multicolumn{2}{|c|}{$\begin{array}{l}\text { What economic diversification options exist for the Australia steel manufacturing sector? } \\
\text { How will tagging of steel properties in infrastructure applications affect reuse rates? }\end{array}$} & $\begin{array}{l}\text { What will be the effect of recycling } \\
\text { in China on iron ore demand from } \\
\text { Australia? }\end{array}$ \\
\hline Gold & \multicolumn{3}{|c|}{ How will e-waste recovery of gold affect Australian supply (the gold content of electronics can determine the economics of recycling)? } \\
\hline Aluminium & $\begin{array}{l}\text { How might container deposit and other } \\
\text { extended producer legislation for aluminium } \\
\text { or e-waste foster drop off centres, change } \\
\text { recycling economics and support city-based } \\
\text { mini-recycling plants? }\end{array}$ & \multicolumn{2}{|c|}{$\begin{array}{l}\text { How may the relative export demand for Australian bauxite shift as the geography of aluminium } \\
\text { smelting shifts to lower carbon intensity and lower cost electricity jurisdictions? How might } \\
\text { investment in clean energy in place of coal based power affect the economics of aluminium } \\
\text { production in Australia, in light of recent closure of local aluminium smelting capacity? }\end{array}$} \\
\hline $\begin{array}{l}\text { Manufacturing } \\
\text { and design }\end{array}$ & $\begin{array}{l}\text { How could distributed design and additive } \\
\text { manufacturing reshape both manufacturing } \\
\text { and recycling in Australia for improved social } \\
\text { and environmental outcomes? }\end{array}$ & \multicolumn{2}{|c|}{$\begin{array}{c}\text { What is Australia's competitive advantage in new global markets for manufacturing and design } \\
\text { such as leasing 'responsibly sourced (or recycled) metals' to additive manufacturers? } \\
\text { What is required to ensure additive manufacturing is resource efficient? }\end{array}$} \\
\hline
\end{tabular}

Waste and 
Overall, these factors influence the scale of closing the loop in terms of economic benefit and environmental and social value. They require a future research agenda which includes a better integrated understanding of circular economy business models and implications for Australia's future metals management and prosperity.

\section{Acknowledgments}

This research was undertaken as part of the Wealth from Waste Research Cluster, a collaborative program between the Australian Commonwealth Scientific Industrial Research Organisation (CSIRO); University of Technology, Sydney; The University of Queensland, Swinburne University of Technology, Monash University and Yale University. The authors gratefully acknowledge the contribution each partner and the CSIRO Flagship Collaboration Fund. The Wealth from Waste Research Cluster is a part of the Minerals Down Under National Research Flagship and is supported by the Future Manufacturing National Research Flagship. Thanks a lot to Leah Mason and Toby Gray for valuable discussions and to Sarah King, Artem Golev, Glen Corder and Saleem Ali for comments on the paper.

\section{Author Contributions}

Anna Littleboy contributed to the introduction and the section on circular economy. Damien Giurco contributed to the introduction, section on circular economy and the Australian context, and wrote the text on responsible supply chains. The section on trends in additive manufacturing was written by Thomas Boyle, while the sub-sections relating to waste in the Australian context were written by Julian Fyfe. The concluding discussion was written by Damien Giurco with input from Stuart White.

\section{Conflicts of Interest}

The authors declare no conflict of interest.

\section{References}

1. Erten, B.; Ocampo, J.A. Super Cycles of Commodity Prices Since the Mid-Nineteenth Century. In Initiative for Policy Dialogue Working Paper Series; Initiative for Policy Dialogue: New York, NY, USA, 2012.

2. Jacks, D.S. From Boom to Bust: A Typology of Real Commodity Prices in the Long Run; National Bureau of Economic Research: Cambridge, MA, USA, 2013.

3. Hajkowicz, S.; Cook, H.; Littleboy, A. Our Future World: Global Megatrends that will Change the Way We Live. The 2012 Revision; Commonwealth Scientific Industrial Research Organisation (CSIRO): Brisbane, Australia, 2012.

4. Giurco, D.; McLellan, B.; Franks, D.; Nansai, K.; Prior, T. Responsible mineral and energy futures: Global perspectives. J. Clean. Prod. 2014, Submitted.

5. Graedel, T.E.; Harper, E.M.; Nassar, N.T.; Reck, B.K. On the materials basis of modern society. Proc. Natl. Acad. Sci. USA 2013, 2013, doi:10.1073/pnas.1312752110. 
6. Valero, A.; Valero, A.; Martínez, A. Inventory of the exergy resources on earth including its mineral capital. Energy 2010, 35, 989-995.

7. Mason, L.; Prior, T.; Mudd, G.; Giurco, D. Availability, addiction and alternatives: three criteria for assessing the impact of peak minerals on society. J. Clean. Prod. 2011, 19, 958-966.

8. Mathews, J.A.; Tan, H. Progress toward a circular economy in China. J. Ind. Ecol. 2011, 15, 435-457.

9. Yuan, Z.; Bi, J.; Moriguichi, Y. The circular economy: A new development strategy in China. J. Ind. Ecol. 2006, 10, 4-8.

10. Su, B.; Heshmati, A.; Geng, Y.; Yu, X. A review of the circular economy in China: Moving from rhetoric to implementation. J. Clean. Prod. 2013, 42, 215-217.

11. Ma, S.-H.; Wen, Z.-G.; Chen, J.-N.; Wen, Z.-C. Mode of circular economy in China's iron and steel industry: A case study in Wu'an city. J. Clean. Prod. 2013, 64, 505-512.

12. Pearce, D.W.; Turner, R.K. Economics of Natural Resources and the Environment; Johns Hopkins University Press: Baltimore, MA, USA, 1990.

13. Towards the Circular Economy; Ellen Macarthur Foundation: Isle of Wight, UK, 2012; Volume 1.

14. West, J.; Schandl, H.; Heyenga, S.; Chen, S. Resource Efficiency: Economics and Outlook for China; United Nations Environment Programme (UNEP): Bangkok, Thailand, 2013.

15. Mudd, G.M. The environmental sustainability of mining in Australia: Key mega-trends and looming constraints. Resour. Policy 2010, 35, 98-115.

16. Prior, T.; Giurco, D.; Mudd, G.; Mason, L.; Behrisch, J. Resource depletion, peak minerals and the implications for sustainable resource management. Glob. Environ. Change 2012, 22, 577-587.

17. Hoornweg, D.; Bhada-Tata, P. What a Waste: A Global Review of Solid Waste Management; The World Bank: Washington, WA, USA, 2012.

18. Reuter, M.A.; van Schaik, A.; Heiskanen, K.; Meskers, C.; Hagelüken, C. Metal Recycling: Opportunities, Limits, Infrastructure; UNEP: New York, NY, USA, 2013.

19. Green, J.A. Aluminum Recycling and Processing for Energy Conservation and Sustainability; ASM International: Materials Park, OH, USA, 2007.

20. Giurco, D.; Stewart, M.; Suljada, T.; Petrie, J. Copper Recycling Alternatives: An Environmental Analysis. In Proceedings of the 5th Annual Environmental Engineering Research Event, Noosa, Australia, 20-23 October 2006.

21. Davenport, W.G.L.; King, M.; Schlesinger, M.; Biswas, A.K. Extractive Metallurgy of Copper; Elsevier: Oxford, UK, 2002.

22. Giurco, D. Towards Sustainable Metal Cycles: The Case of Copper. Ph.D. Thesis, University of Sydney, Sydney, Australia, 2005.

23. Schluep, M. Overview Sustainable Recycling Industries (SRI). In Sustainable Recycling Industries: Advance Raw Materials Stewardship in Developing Countries; EMPA: ETH Zurich, Swezerland, 2013.

24. Clapp, J. Toxic Exports: The Transfer of Hazardous Wastes from Rich to Poor Countries; Cornell University Press: Ithica, NY, USA, 2001.

25. Ogushi, Y.; Kandlikar, M. Assessing extended producer responsibility laws in Japan. Environ. Sci. Technol. 2007, 41, 4502-4508.

26. Geng, Y.; Fu, J.; Sarkis, J.; Xue, B. Towards a national circular economy indicator system in China: An evaluation and critical analysis. J. Clean. Prod. 2012, 23, 216-224. 
27. China's Twelfth Five Year Plan (2011-2015)_-The Full English Version. Available online: http://www.britishchamber.cn/content/chinas-twelfth-five-year-plan-2011-2015-full-english-version (accessed on 3 February 2014).

28. Department of Foreign Affairs and Trade Australia's trade with the world graph-Trade Matters Available online: http://www.dfat.gov.au/tradematters/aus-graph.html (accessed on 12 November 2013).

29. Northey, S.; Mohr, S.; Mudd, G.M.; Weng, Z.; Giurco, D. Modelling future copper ore grade decline based on a detailed assessment of copper resources and mining. Resour. Conserv. Recycl. 2013, 83, 190-201.

30. Laurance, W.F.; Koh, L.P.; Butler, R.; Sodhi, N.S.; Bradshaw, C.J.; Neidel, J.D.; Consunji, H.; Mateo Vega, J. Improving the performance of the roundtable on sustainable palm oil for nature conservation. Conserv. Biol. 2010, 24, 377-381.

31. FSC Principles and Criteria for Forest Stewardship; Forest Stewardship Council: Bonn, Germany, 2004.

32. Sarin, R. No dirty gold: Consumer education and action for mining reform. J. Clean. Prod. 2006, 14, 305-306.

33. Responsible Jewellery Council. Available online: http://www.responsiblejewellery.com/ (accessed on 1 December 2013).

34. Steel Stewardship Forum. Available online: http://www.steelstewardship.com (accessed on 1 December 2013).

35. Berkhout, P.H.G.; Muskens, J.C.; Velthuijsen, J.W. Defining the rebound effect. Energy Policy 2000, 28, 425-432.

36. Cooper, C.; Giurco, D. Mineral resources landscape: Reconciling complexity, sustainability and technology. Int. J. Technol. Intell. Plan. 2011, 7, 1-18.

37. Zhang, K.; Schnoor, J.L.; Zeng, E.Y. E-waste recycling: Where does it go from here? Environ. Sci. Technol. 2012, 46, 10861-10867.

38. Schluep, M. Recycling: From E-Waste to Resources; UNEP and United Nations University: Tokyo, Japan, 2009.

39. Jolly, J. 2013 Technical Report-The US Copper-Base Scrap Industry and Its By-Products. Available online: http://www.copper.org/publications/pub_list/pdf/scrap_report.pdf (accessed on 1 December 2103).

40. Graedel, T.; Allwood, J.; Birat, J.-P.; Buchert, M.; Hagelüken, C.; Reck, B.K.; Sibley, S.F.; Sonnemann, G. Recycling Rates of Metals: A Status Report; UNEP: Paris, France, 2011.

41. Schandl, H.; West, J. Resource use and resource efficiency in the Asia-Pacific region. Glob. Environ. Chang. 2010, 20, 636-647.

42. Mironov, V.; Boland, T.; Trusk, T.; Forgacs, G.; Markwald, R.R. Organ printing: Computer-aided jet-based 3D tissue engineering. TRENDS Biotechnol. 2003, 21, 157-161.

43. National Aeronautics and Space Administration (NASA). NASA Tests Limits of 3-D Printing with Powerful Rocket Engine Check. Available online: http:/www.nasa.gov/exploration/systems/sls/ 3d-printed-rocket-injector.html (accessed on 1 December 2013).

44. Rosen, D.; Weiss, L. Layered manufacturing: Current status and future trends. J. Comput. Inf. Sci. Eng. 2001, 1, 60-71. 
45. Bak, D. Rapid prototyping or rapid production? 3D printing processes move industry towards the latter. Assem. Autom. 2003, 23, 340-345.

46. Markets and Markets Global Additive Manufacturing Market worth \$3.5 Billion by 2017. Available online: http://www.marketsandmarkets.com/PressReleases/additive-manufacturing.asp (accessed on 1 November 2013).

47. Wholers Associates. Wholers Report 2013; Wohlers Associates, Inc.: Fort Collins, CO, USA, 2013. Available online: http://wohlersassociates.com/2013report.htm (accessed on 1 November 2013).

48. Wohlers Associates. Additive Manufacturing Technology for Australia; CSIRO and Enterprise Connect: Fort Collins, CO, USA, 2011.

49. Kaur, S. Pushing frontiers with the first lady of emerging technologies-How is "Internet of the 3D printed products" going to affect our lives? IETE Tech. Rev. 2012, 29, 360-364.

50. Why You Won't Have an AM Machine in Your Garage: MTAdditive. Available online: http://www.mtadditive.com/articles/why-you-wont-have-an-am-machine-in-your-garage (accessed on 1 November 2013).

51. Wohlers Talk Why Most Adults Will Never Use a 3D Printer. Available online: http://wohlersassociates.com/blog/2012/07/why-most-adults-will-never-use-a-3d-printer/ (accessed on 8 April 2014.)

52. Bilton, R. Microsoft's Brilliantly Simple 3D Printing Mission: Make It just Like 2D Printing. Available online: http://venturebeat.com/2013/08/23/microsofts-briliantly-simple-3d-printingmission-make-it-just-like-2d-printing/ (1 November 2013).

53. Shapeways Make, Buy, and Sell Products with 3D Printing. Available online: http://www.shapeways.com/ (1 November 2013).

54. Bourell, D.; Beaman, J.; Leu, M.; Rosen, D. A Brief History of Additive Manufacturing and the 2009 Roadmap for Additive Manufacturing: Looking back and Looking ahead. In Proceedings of the US-Turkey Workshop on Rapid Technologies, Istanbul, Turkey, 24-25 September 2009.

55. Department of Foreign Affairs and Trade Australia's Trade in Goods and Services 2012-2013. Available online: http://dfat.gov.au/publications/tgs/index.html (accessed on 8 April 2014).

56. Australian Bureau of Statistics. 1301.0-Year Book of Australia, 2012. Available online: http://www.abs.gov.au/ausstats/abs@.nsf/Lookup/by\%20Subject/1301.0 2012 Main\%20Features $\sim$ Mining\%20Industry 150 (accessed on 8 April 2014).

57. Giurco, D.; Evans, G.; Cooper, C.; Mason, L.; Franks, D. Mineral Futures Discussion Paper: Sustainability Issues, Challenges and Opportunities; Institute for Sustainable Futures, UTS and Sustainable Minerals Institute, Univeristy of Queensland: Sydney, Australia, 2009.

58. Giurco, D.; Prior, T.; Mudd, G.; Mason, L.; Behrisch, J. Peak Minerals in Australia: A Review of Changing Impacts and Benefits; Institute for Sustainable Futures, University of Technology, Sydney (UTS): Sydney, Australia, 2010.

59. Oke, M.; Allan, P.; Goldsworthy, K; Pickin, J. Waste and Recycling in Australia Report No 1; Hyder for Department of Environment Water Heritage and the Arts: Canberra, Australia, 2008.

60. Smith, K.; O’Farrell, K.; Brindley, F. Waste and Recycling in Australia 2011; Hyder for Department of Environment Water Heritage and the Arts: Canberra, Australia, 2012. 
61. Australian Government. National Waste Report 2010; Environment Protection and Heritage Council (EPHC) and Department of Environment Water Heritage and the Arts: Canberra, Australia, 2010.

62. van Beers, D.; Corder, G.D.; Bossilkov, A.; van Berkel, R. Regional synergies in the Australian minerals industry: Case-studies and enabling tools. Miner. Eng. 2007, 20, 830-841.

63. Giurco, D.; Cohen, B.; Langham, E.; Warnken, M. Backcasting energy futures using industrial ecology. Technol. Forcasting Soc. Change 2011, 78, 797-818.

64. Golev, A.; Corder, G.D.; Giurco, D.P. Industrial symbiosis in Gladstone: A decade of progress and future development. J. Clean. Prod. 2014, doi: 10.1016/j.jclepro.2013.06.054.

65. Corder, G.; Golev, A.; King, S.; Fyfe, J. Barriers and enablers to industrial ecology in Australia. Resources 2014, 3, 340-361.

66. Scrap Metal Recycling Industry in Australia Report OD4044; IBISWorld: Melbourne, Australia, 2013.

67. A Study into Commercial and Industrial (C\&I) Waste and Recycling by Industry Division; Sustainable Resource Use Pty Ltd.: North Melbourne, Austrilia, 2012.

68. Davey, C. National Steel Can Recycling Survey 2006-2007 and 2007-2008; Hyder for the Australian Food and Grocery Council and the National Packaging Covenant Council: Canberra, Australia, 2008.

69. SITA. The Facts about Steel and Aluminium. Available online: http://www.sita.com.au/ media/fact_sheets/AL_Facts_24.1.12.pdf (accessed on 1 December 2013).

70. Yellishetty, M.; Mudd, G.; Ranjith, P.G.; Tharumarajah, A. Environmental life-cycle comparisons of steel production and recycling: Sustainability issues, problems and prospects. Environ. Sci. Policy 2011, 14, 650-663.

71. Steel Recycling Institute. Available online: http://www.recycle-steel.org/ (accessed on 8 April 2014).

72. Preston, F. A Global Redesign? Shaping the Circular Economy; Chatham House: London, UK, 2012. Available online: http://www.chathamhouse.org/sites/default/files/public/Research/ Energy,\%20Environment\%20and\%20Development/bp0312_preston.pdf (accessed on 8 April 2014).

(C) 2014 by the authors; licensee MDPI, Basel, Switzerland. This article is an open access article distributed under the terms and conditions of the Creative Commons Attribution license (http://creativecommons.org/licenses/by/3.0/). 